\title{
Current developments in nanosafety research
}

\author{
Seddik Hammad $\cdot$ Hermann M. Bolt
}

Received: 22 October 2014 / Accepted: 23 October 2014 / Published online: 25 November 2014

(C) Springer-Verlag Berlin Heidelberg 2014

Analyzing the most intensively studied fields of research based on the articles published in our journal, it becomes clear that nanotoxicology remains one of the most popular topics (Gebel et al. 2013; Cadenas et al. 2012; Hoelting et al. 2013; Bolt et al. 2012; Kroll et al. 2012; Nohynek and Dufour 2012; Marchan 2012; Hengstler 2011; Haase et al. 2012; Landsiedel et al. 2012a, b; Klein et al. 2012; Kim et al. 2012; Hadrup et al. 2012; Creutzenberg 2012; Stewart and Marchan 2012). Publications in recent years focused on the influence of size (Xiong et al. 2013a), shape (Zhao et al. 2013; Xiong et al. 2013b), the corona (Böhmert et al. 2012), report about uptake by endocytosis (Kasper et al. 2013) and confirm generation of oxidative stress, release of cytokines and apoptosis as well as autophagy as mechanisms triggered by exposure to nanoparticles (Guo et al. 2013; Xu et al. 2013; Trpkovic et al. 2012; Morishige et al. 2012). However, the articles published in the past 2 years do not report basically new mechanisms of action of nanoparticles (Donaldson and Poland 2013; Safe Work Australia 2009; Donaldson et al. 2010; NIOSH 2013). Also comprehensive reviews on kinetics, particle translocation, and systemic toxicity (Landsiedel et al. 2012a, b), genotoxicity (Magdolenova et al. 2014; Singh et al. 2009; Shi et al. 2013; Kumar and Dhawan 2013), material characterization (Warheit

\footnotetext{
S. Hammad $(\bowtie)$

Department of Forensic Medicine and Veterinary Toxicology, Faculty of Veterinary Medicine, South Valley University, Qena, Egypt

e-mail: Seddik.hammad@vet.svu.edu.eg; el-kariem@ifado.de
}

H. M. Bolt

Leibniz Research Centre for Working Environment and Human

Factors, Technical University of Dortmund (IfADo),

44139 Dortmund, Germany

e-mail: bolt@ifado.de
2008, 2010), physico-chemical features (Fubini et al. 2010; Rivera et al. 2010) and concepts of risk assessment (Dankovic et al. 2007; Sayes et al. 2013; Stone et al. 2014; Kuempel et al. 2012) have already been published. Considering this background, it may be questioned whether we really need so many further studies showing again that nanoparticles may induce oxidative stress, release pro-inflammatory cytokines and show size-dependent differences. What are the key questions that should be preferentially addressed by nanotoxicology? Recently, it has been reported that despite of intensive research, not a single nano-specific toxic mechanism has been discovered (Donaldson and Poland 2013). Nanoparticles act by the chemicals released, reactions catalyzed by their surface or by mechanisms already known from particle toxicology for materials with a primary particle diameter higher than $100 \mathrm{~nm}$. A recent review systematically compared rat inhalation studies performed with respirable granular biodurable particles with diameters of smaller and larger than $100 \mathrm{~nm}$ (Gebel 2012). The difference in carcinogenic potency between nano- and micromaterials was relatively small ranging between two and five depending on the individual study. Although size and shape of particles have been shown to be influential, the factor of the size effect may be smaller than hitherto expected. It is also no longer particularly helpful to illustrate in vitro that, e.g., neuronal cells can be compromised by certain nanoparticles. A critical question for risk assessment is whether toxic concentrations can really be reached in human target tissues (Henrich-Noack 2012). Further, it would be of high practical relevance if groups of nanoparticles can be defined to facilitate risk evaluation. It might occur that in some years, nanotoxicology will no longer be seen as a specific subdiscipline in toxicity, since toxic effects of nanoparticles may be sufficiently explained by already well-established mechanisms of chemical and particle toxicology. 


\section{References}

Böhmert L, Niemann B, Thünemann AF, Lampen A (2012) Cytotoxicity of peptide-coated silver nanoparticles on the human intestinal cell line Caco-2. Arch Toxicol 86(7):1107-1115

Bolt HM, Marchan R, Hengstler JG (2012) Nanotoxicology and oxidative stress control: cutting-edge topics in toxicology. Arch Toxicol 86(11):1629-1635

Cadenas C, Marchan R, Hengstler JG (2012) Buckyballs (fullerenes): free radical sponges or inflammatory agents? Arch Toxicol 12:1807-1808

Creutzenberg O (2012) Biological interactions and toxicity of nanomaterials in the respiratory tract and various approaches of aerosol generation for toxicity testing. Arch Toxicol 86(7): $1117-1122$

Dankovic D, Kuempel E, Wheeler M (2007) An approach to risk assessment for $\mathrm{TiO}_{2}$. Inhal Toxicol 19(Suppl 1):205-212

Donaldson K, Poland CA (2013) Nanotoxicity: challenging the myth of nano-specific toxicity. Curr Opin Biotechnol 24:724-734

Donaldson K, Murphy FA, Duffin R, Poland CA (2010) Asbestos, carbon nanotubes and the pleural mesothelium: a review of the hypothesis regarding the role of long fibre retention in the parietal pleura, inflammation and mesothelioma. Part Fibre Toxicol 7:5

Fubini B, Ghiazza M, Fenoglio I (2010) Physico-chemical features of engineered nanoparticles relevant to their toxicity. Nanotoxicology 4:347-363

Gebel T (2012) Small difference in carcinogenic potency between GBP nanomaterials and GBP micromaterials. Arch Toxicol 86(7):995-1007

Gebel T, Marchan R, Hengstler JG (2013) The nanotoxicology revolution. Arch Toxicol 87(12):2057-2062

Guo J, Gu N, Chen J, Shi T, Zhou Y, Rong Y, Zhou T, Yang W, Cui X, Chen W (2013) Neutralization of interleukin-1 beta attenuates silica-induced lung inflammation and fibrosis in C57BL/6 mice. Arch Toxicol 87(11):1963-1973

Haase A, Mantion A, Graf P, Plendl J, Thuenemann AF, Meier W, Taubert A, Luch A (2012) A novel type of silver nanoparticles and their advantages in toxicity testing in cell culture systems. Arch Toxicol 86(7):1089-1098

Hadrup N, Loeschner K, Bergström A, Wilcks A, Gao X, Vogel U, Frandsen HL, Larsen EH, Lam HR, Mortensen A (2012) Subacute oral toxicity investigation of nanoparticulate and ionic silver in rats. Arch Toxicol 86(4):543-551

Hengstler JG (2011) Cutting-edge topics in toxicology. EXCLI J 10:117-119

Henrich-Noack P, Prilloff S, Voigt N, Jin J, Hintz W, Tomas J, Sabel BA (2012) In vivo visualisation of nanoparticle entry into central nervous system tissue. Arch Toxicol 86(7):1099-1105

Hoelting L, Scheinhardt B, Bondarenko O, Schildknecht S, Kapitza M, Tanavde V, Tan B, Lee QY, Mecking S, Leist M, Kadereit S (2013) A 3-dimensional human embryonic stem cell (hESC)derived model to detect developmental neurotoxicity of nanoparticles. Arch Toxicol 87(4):721-733

Kasper J, Hermanns MI, Bantz C, Koshkina O, Lang T, Maskos M, Pohl C, Unger RE, Kirkpatrick CJ (2013) Interactions of silica nanoparticles with lung epithelial cells and the association to flotillins. Arch Toxicol 87(6):1053-1065

Kim JE, Shin JY, Cho MH (2012) Magnetic nanoparticles: an update of application for drug delivery and possible toxic effects. Arch Toxicol 86(5):685-700

Klein CL, Wiench K, Wiemann M, Ma-Hock L, van Ravenzwaay B, Landsiedel R (2012) Hazard identification of inhaled nanomaterials: making use of short-term inhalation studies. Arch Toxicol 86(7):1137-1151
Kroll A, Pillukat MH, Hahn D, Schnekenburger J (2012) Interference of engineered nanoparticles with in vitro toxicity assays. Arch Toxicol 86(7):1123-1136

Kuempel ED, Castranova V, Geraci CL, Schulte PA (2012) Development of risk-based nanomaterial groups for occupational exposure control. J Nanopart Res 14:1029

Kumar A, Dhawan A (2013) Genotoxic and carcinogenic potential of engineered nanoparticles: an update. Arch Toxicol 87:1883-1900

Landsiedel R, Fabian E, Ma-Hock L, van Ravenzwaay B, Wohlleben W, Wiench K, Oesch F (2012a) Toxico-/biokinetics of nanomaterials. Arch Toxicol 86(7):1021-1060. Review. Erratum in: Arch Toxicol. 2012 Jul; 86(7):1061

Landsiedel R, Fabian E, Ma-Hock L, Wohlleben W, Wiench K, Oesch F, van Ravenzwaay B (2012b) Toxico-/biokinetics of nanomaterials. Arch Toxicol 86:1021-1060

Magdolenova Z, Collins A, Kumar A, Dhawan A, Stone V, Dusinska M (2014) Mechanisms of genotoxicity. A review of in vitro and in vivo studies with engineered nanoparticles. Nanotoxicology 8:233-278

Marchan R (2012) A special issue on nanotoxicology. EXCLI J 11:176-177

Morishige T, Yoshioka Y, Inakura H, Tanabe A, Narimatsu S, Yao X, Monobe Y, Imazawa T, Tsunoda S, Tsutsumi Y, Mukai Y, Okada N, Nakagawa S (2012) Suppression of nanosilica particleinduced inflammation by surface modification of the particles. Arch Toxicol 86(8):1297-1307

NIOSH (2013) Current Intelligence Bulletin 65: Occupational Exposure to Carbon Nanotubes and Nanofibers. National Institute for Occupational Safety and Health (NIOSH) Centers for Disease Control and Prevention. http://www.cdc.gov/niosh/ docs/2013-145/

Nohynek GJ, Dufour EK (2012) Nano-sized cosmetic formulations or solid nanoparticles in sunscreens: a risk to human health? Arch Toxicol 86(7):1063-1075

Rivera Gil P, Oberdörster G, Elder A, Puntes V, Parak WJ (2010) Correlating physi-co-chemical with toxicological properties of nanoparticles: the present and the future. ACS Nano 4:5527-5531

Safe Work Australia (2009) Engineered Nanomaterials: a review of the toxicology and health hazards. p 182. ISBN 9780642329219

Sayes CM, Smith PA, Ivanov IV (2013) A framework for grouping nanoparticles based on their measurable characteristics. Int $\mathrm{J}$ Nanomedicine 8(Suppl 1):45-56

Shi H, Magaye R, Castranova V, Zhao J (2013) Titanium dioxide nanoparticles: a review of current toxicological data. Part Fibre Toxicol 10:15

Singh N, Manshian B, Jenkins GJ, Griffiths SM, Williams PM, Maffeis TG, Wright CJ, Doak SH (2009) NanoGenotoxicology: the DNA damaging potential of engineered nanomaterials. Biomaterials 30:3891-3914

Stewart JD, Marchan R (2012) Current developments in toxicology. EXCLI J 11:692-702

Stone V, Pozzi-Mucelli S, Tran L, Aschberger K, Sabella S, Vogel U, Poland C, Balharry D, Fernandes T, Gottardo S, Hankin S, Hartl MG, Hartmann N, Hristozov D, Hund-Rinke K, Johnston H, Marcomini A, Panzer O, Roncato D, Saber AT, Wallin H, Scott-Fordsmand JJ (2014) ITS-NANO-prioritising nanosafety research to develop a stakeholder driven intelligent testing strategy. Part Fibre Toxicol 11:9

Trpkovic A, Todorovic-Markovic B, Trajkovic V (2012) Toxicity of pristine versus functionalized fullerenes: mechanisms of cell damage and the role of oxidative stress. Arch Toxicol 86(12):1809-1827

Warheit DB (2008) How meaningful are the results of nanotoxicity studies in the absence of adequate material characterization? Toxicol Sci 101(2):183-185 
Warheit DB (2010) Debunking some misconceptions about nanotoxicology. Nano Lett 10(12):4777-4782

Xiong S, George S, Yu H, Damoiseaux R, France B, Ng KW, Loo JS (2013a) Size influences the cytotoxicity of poly (lactic-co-glycolic acid) (PLGA) and titanium dioxide $\left(\mathrm{TiO}_{2}\right)$ nano-particles. Arch Toxicol 87(6):1075-1086

Xiong S, George S, Ji Z, Lin S, Yu H, Damoiseaux R, France B, $\mathrm{Ng} \mathrm{KW}$, Loo SC (2013b) Size of $\mathrm{TiO}_{2}$ nanoparticles influences their phototoxicity: an in vitro investigation. Arch Toxicol 87(1):99-109

Xu J, Li Z, Xu P, Xiao L, Yang Z (2013) Nanosized copper oxide induces apoptosis through oxidative stress in podocytes. Arch Toxicol 87(6):1067-1073

Zhao X, Ng S, Heng BC, Guo J, Ma L, Tan TT, Ng KW, Loo SC (2013) Cytotoxicity of hydroxyapatite nanoparticles is shape and cell dependent. Arch Toxicol 87(6):1037-1052 